\title{
Pembelajaran Pendidikan Agama Islam (PAI) di Sekolah Dasar
}

\author{
Asep Abdul Aziz \\ Universitas Islam Negeri (UIN) Sunan Gunung Djati Bandung \\ Email: asepabdulaziz1993@gmail.com \\ Ajat Syarif Hidayatullah \\ Universitas Islam Negeri (UIN) Sunan Gunung Djati Bandung \\ Email: syarifhidayatullohoo3@gmail.com \\ Uus Ruswandi \\ Universitas Islam Negeri (UIN) Sunan Gunung Djati Bandung \\ Email: uusruswandi@uinsgd.ac.id

\section{Bambang Samsul Arifin} \\ Universitas Islam Negeri (UIN) Sunan Gunung Djati Bandung \\ Email: bambangsamsularifin@uinsgd.ac.id
}

Received: January 28, 2021 | Accepted: June 19, 2021

\begin{abstract}
This article aims to reveal the concept of Islamic religious education learning in elementary schools.In the development of primary school age children have their own characteristics, the ability to think of elementary school age children develop gradually. It needs to be understood wisely to be able to deliver successful educational goals. This research adopts a descriptive qualitative approach with library research methods. The results showed that Islamic religious education in elementary school is quite unique, if in the past the mind of the child is still imaginative and egocentric then at this time the child's mind develops towards concrete, rational and objective thinking. The scope of islamic religious education study is the Qur'an, religion, morals, fiqh / worship, and islamic cultural history. The method of education that can be applied refers to the Qurani method namely amstal method, qishah method, ibrah mauidzah method, hiwar jadali method, uswah hasanah method, and targhib tarhib method. Meanwhile, Islamic education can be carried out verbally or non verbally, writing or non-writing aimed at measuring intellectual komptensi, social competence, social competence and spiritual competence. Thus, Islamic religious education is expected to produce people who always strive to perfect faith, piety, and morality, and actively build Islamic civilization.
\end{abstract}




\begin{abstract}
Abstrak
Artikel ini bertujuan untuk mengungkapkan konsep pembelajaran pendidikan agama Islam di sekolah dasar. Perkembangannya anak usia Sekolah Dasar memiliki ciri khasnya tersendiri, kemampuan berfikir anak usia Sekolah Dasar berkembang secara berangsur-angsur. Perlu dipahami secara bijak untuk dapat mengantarkan keberhasilan tujuan pendidikan. Penelitian ini menggunkaan pendekatan kualitatif deskriptif dengan metode studi pustaka (library research). Hasil penelitian menunjukan bahwa pendidikan agama Islam di sekolah dasar cukup unik, jika pada masa sebelumnya daya fikir anak masih bersifat imajinatif dan egosentris maka pada masa ini daya pikir anak · berkembang kearah berpikir kongkrit, rasional dan objektif. Adapun ruang lingkup kajian pendidikan agama Islam yaitu Al-Qur'an, akidah, akhlak, fiqh/ibadah, dan sejarah kebudayaan Islam. Metode pendidikan yang bisa diterapkan mengacu kepada metode Qurani yakni metode amstal, metode qishah, metode ibrah mauidzah, metode hiwar jadali, metode uswah hasanah, dan metode targhib tarhib. Sementara itu, pendidikan Agama Islam bisa dilaksanakan secara secara verbal ataupun non verbal, tulis maupun non tulis yang ditujukan untuk mengukur komptensi intelektual, kompetensi sosial, kompetensi sosial dan kompetensi spiritual. Dengan demikian, pendidikan agama Islam diharapkan menghasilkan manusia yang selalu berupaya menyempurnakan iman, takwa, dan akhlak, serta aktif membangun peradaban Islam.
\end{abstract}

\title{
Keywords
}

Learning, Islamic education, elementary school

\section{Pendahuluan}

Kegiatan pendidikan yang dilaksanakan oleh umat Islam atau apa yang sering disebut dengan pendidikan Islam menjangkau semua interaksi edukatif, baik melalui jalur sekolah maupun luar sekolah (Efendi, Lubis, and Nasution, 2018). Kegiatan pendidikan Islam melalui jalur luar sekolah antara lain tercermin dalam kegiatan majelis ta`lim, pengajian, pondok pesantren dan lain-lain. Sementara itu, pendidikan Islam melalui jalur sekolah antara lain diwujudkan dalam bentuk lembaga pendidikan Islam formal seperti RA, MI, MTs, MA, IAIN/STAIN/PTAIS, dan pelajaran Pendidikan Agama Islam (PAI) di lembaga pendidikan (sekolah) umum. Keberadaan PAI dalam keseluruhan isi kurikulum sekolah umum memang dijamin oleh UU No. 20 Tahun 2003 tentang Sistem Pendidikan Nasional bab X pasal 37 "Kurikulum pendidikan dasar dan menengah wajib memuat: pendidikan agama. Bahkan PAI merupakan salah satu mata pelajaran wajib 
yang harus diajarkan di setiap jalur, jenis dan jenjang pendidikan baik negeri maupun swasta (Hartati, 2017).

Pendidikan Agama Islam (PAI) sebagai salah satu mata pelajaran yang diajarkan di sekolah memiliki peranan yang sangat strategis untuk membentuk kepribadian umat dan bangsa (peserta didik) yang tangguh; baik dari segi moralitas maupun dari aspek sains dan teknologi (Nugraha, Supriadi, dan Anwar, 2014). Namun, kenyatan yang kita lihat sekarang ini pembelajaran PAI di sekolah menjadi sorotan para pakar pendidikan bahwa pembelajaran PAI kurang berhasil dalam menanamkan nilai-nilai moral dan agama kepada peserta didik. Hal ini dapat dilihat maraknya terjadi fatologi sosial pada remaja (pelajar), seperti penyalagunaan Narkoba, begal, pergaulan bebas dan tawuran, serta penyakit sosial lainnya (Hartati, 2015). Kesemua itu merupakan bukti yang menguatkan bahwa pola strategi pembelajaran PAI di sekolah dewasa ini berjalan secara konvensionaltradisional serta penuh dengan keterbatasan (Tang, 2018). Di samping itu, pengembangan pembelajaran PAI sekarang ini kurang merespon perkembangan zaman revolusi industry 4.0. Padahal apabila kita lihat realita peserta didik sekarang ini, mereka pada umumnya sangat akrab dengan alat digital seperti, hand phone smart, laptop, dan alat digital lainnya. Seyogyanya, sebagai seorang pendidik PAI yang responsif melihat kondisi tersebut akan bersikap inovatif dan kreatif mengembangkan strategi pembelajaran yang sesuai dengan dunia anak-anak (peserta didik) sekarang ini (Fakhruddin, 2014).

Menurut Zakiyah Darajat, Pendidikan Agama Islam adalah suatu usaha untuk membina dan mengasuh peserta didik agar senantiasa dapat memahami ajaran Islam secara menyeluruh, menghayati tujuan, dan pada akhirnya dapat mengamalkan serta menjadikan Islam sebagai pandangan hidup. Oleh karena itu, ketika kita menyebut pendidikan Islam, maka akan mencakup dua hal, yaitu: pertama mendidik siswa agar untuk berperilaku sesuai dengan nilai-nilai atau akhlak yang lslami. kedua, mendidik siswasiswi untuk mempelajari materi ajaran Islam (subjek pelajaran berupa pengetahuan tentang ajaran Islam)(Utomo, 2018). Mata pelajaran Pendidikan Agama Islam (PAl) di Sekolah Dasar (SD) secara keseluruhan berada pada lingkup al-Qur'an dan ai-Hadits, keimanan, akhlaq, fiqih, dan sejarah. Ruang lingkup pendidikan agama Islam mencakup pewujudan keserasian, keselarasan dan keseimbangan hubungan manusia dengan Allah, diri sendiri, sesama manusia, mahluk Iainnya maupun lingkungannya (Hablun minallah wa hablun minannas). Jadi pendidikan agama Islam merupakan usaha sadar yang dilakukan pendidik dalam rangka mempersiapkan peserta didik untuk meyakini, memahami, dan mengamalkan ajaran Islam melalui kegiatan bimbingan, pengajaran atau 
pelatihan yang telah ditentukan untuk mencapai tujuan yang telah ditetapkan (Sulistyowati, 2012).

Peranan guru dalam kegiatan belajar mengajar sangatlah besar, seorang guru harus mampu mewujudkan pembelajaran yang aktif, artinya peserta didik diikutsertakan dalam berbagai kegiatan pembelajaran. Dan diharapkan mampu meningkatkan keterlibatan mental peserta didik dalam proses belajar mengajar, peserta didik dalam aspek emosional, spiritual dan intelektualnya (Budiyanti, Rizal, and Sumarna, 2016). Selain itu guru harus mampu menjadi mitra belajar bagi peserta didik, peserta didik akan belajar kalau guru juga belajar. Guru bertanggung jawab untuk meningkatkan situasi yang dapat mendorong prakarsa, motivasi dan tanggung jawab peserta didik dalam suasana yang aktif, sehingga pembelajaran akan mudah dipahami dan berpusat pada peserta didik. Kegiatan pembelajaran peserta didik harus terkait dengan pengetahuan yang telah dimiliki, kecakapan, dan nilai nilai yang diharapkan untuk dikuasai dan dimiliki oleh peserta didik (Shunhaji, 2019).

Berdasarkan latar belakang tersebut, penulis merasa penting mengkaji pembelajaran di Sekolah Dasar secara komprehensif berkatan dengan konsep, tujuan, materi, serta evaluasi yang dilakukan di Sekolah Dasar, agar kita sebagai praktisi pendidikan lebih bijak dan kritis lagi dalam menyesuaikan konsep pembelajaran yang sesuai dengan perkembangan zaman. Konsep pembelajaran di SD menerapkan konsep pendidikan integrative yang berporos pada kepentingan siswa, kecapakan hidup (skill life), serta kenyamanan siswa. Dengan memamahi konsep pembelajaran ini dengan benar maka akan dengan mudah tujuan pembelajaran tercapai dengan maksimal.

\section{Metode}

Penelitian ini menggunakan pendekatan kualitatif deskriptif dengan metode studi pustaka (library research). Adapun teknik pengumpulan datanya dengan cara mengumpulkan beberapa referensi baik berupa buku, artikel, dokumen dan lainnya yang berkaitan denagn pembelajaran Pendidikan Agama Islam di Sekolah Dasar. Teknik analisis dat yang digunakan dalam penelitian ini adalah content analisys (analisis isi) dengan tahapan display data, reduksi data dan penarikan kesimpulan.

\section{Pembelajaran Agama Islam di Sekolah Dasar}

Dasar Pendidikan Agama Islam di SD merupakan bagian dari pendidikan Islam. Pendidikan Islam merupakan subsistem pendidikan 
nasional dan ini sesuai dengan UU No. 2, tahun 1989, tentang pendidikan nasional (Majid, 2004). Pelaksanaan pendidikan agama Islam di pendidikan formal atau sekolah mempunyai dasar-dasar yang sangat kuat, dan ini dapat ditinjau dari beberapa segi, yaitu: Pertama, dasar yuridis. Yaitu dasar pelaksanaan pendidikan agama yang berasal dari peraturan perundangundangan, yang secara langsung maupun tidak Iangsung dapat dijadikan pegangan dalam melaksanakan pendidikan agama, disekolah-sekolah ataupun di lembaga-lembaga pendidikan formal di Indonesia. Adapun dasar yuridis ini dibagi menjadi tiga macam, yaitu: 1) Dasar Ideal: adalah dasar dari Falsafah Negara, dimana sila pertama dari Pancasila adalah 'Ketuhanan Yang Maha Esa'. Ini mengandung pengertian bahwa, seluruh bangsa Indonesia harus percaya kepada Tuhan Yang Maha Esa, atau tegasnya harus beragama. 2) Dasar Operasional: adalah dasar dari UUD 1945. Dalam Bab XI Pasal 29 ayat 1 dan 2, disebutkan: (a) Negara berdasarkan pada Ketuhanan Yang Maha Esa (b) Negara menjamin kemerdekaan tiap-tiap penduduk untuk memeluk agama masing-masing dan beribadah menurut agama dan kepercayaannya tersebut. 2) Dasar Struktural/Konstitusional: adalah dasar yang secara langsung mengatur pelaksanaan pendidikan agama di sekolah-sekolah yang ada di Indonesia, seperti disebutkan dalam Tap MPR No. IV/MPR/1973 yang kemudian dikokohkan lagi pada Tap MPR No. IV/MPR/1978 Jo Ketetapan MPR No. III MPR/1983, Ketetapan MPR No. IIIMPR/1988, Ketetapan MPR No. III MPR/1993 tentang GBHN yang pada pokoknya dinyatakan bahwa pelaksanaan pendidikan agama secara langsung dimasukkan kedalam kurikulum di sekolah-sekolah, mulai dari Sekolah Dasar sampai dengan Universitas-Universitas Negeri (Hartati, 2017).

Kedua, dasar religius. Yang dimaksud dengan dasar religius adalah' dasar yang bersumber dari ajaran Islam. Menurut ajaran Islam pendidikan agama adalah perintah Tuhan dan merupakan perwujudan ibadah kepadaNya. Dalam Al-Quran banyak ayat yang menunjukkan perintah tersebut, antara lain dalam Qs. An-Nahl ayat 125 sebagai berikut:

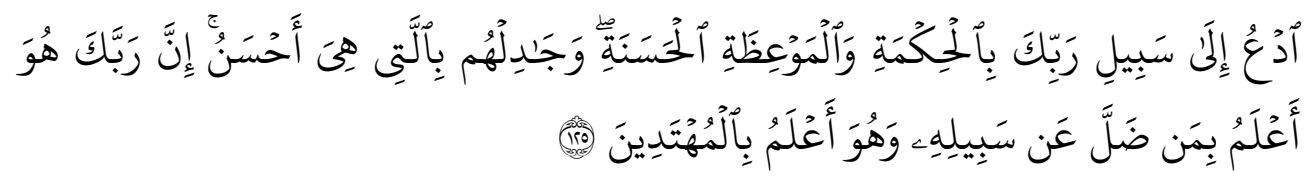

Serulah (manusia) kepada jalan Tuhan-mu dengan hikmah dan pelajaran yang baik dan bantahlah mereka dengan cara yang baik. Sesungguhnya Tuhanmu Dialah yang lebih mengetahui tentang siapa yang tersesat dari jalan-Nya dan Dialah yang lebih mengetahui orang-orang yang mendapat petunjuk" (Qs. An-Nahl: 125)

Ketiga, dasar psikologis. Dasar psikologis adalah dasar yang berhubungan dengan aspek kejiwaan kehidupan individu ataupun 
masyarakat. Sebagaimana diungkapkan oleh Zuhairini dkk, bahwa semua manusia di dunia ini selalu membutuhkan adanya pegangan hidup yang disebut dengan agama. Mereka merasakan bahwa dalam jiwanya ada suatu perasaan yang mengakui adanya zat yang Maha Kuasa, tempat mereka berlindung dan tempat mereka memohon pertolongan-Nya (Sulistyowati, 2012).

Dengan demikian, tiga dasar itulah yang menjadi landasan keberadaan Pendidikan Agama Islam di butuhkan di setiap jenjang pendidikan. Pendidikan Agama Islam memiliki posisi penting dalam sistem pendidikan nasional, pendidikan Agama Islam sering disebut sebagai pendidikan mental moral spiritual bangsa. Karena merupakan salah satu komponen strategis dalam kurikulum pendidikan nasional yang bertanggung jawab terhadap pembinaan watak dan kepribadian bangsa Indonesia dan tergolong dalam muatan wajib kurikulum (Kosim, 2015).

\section{Tahapan Perkembangan Anak Usia Sekolah Dasar}

Perlu diketahui oleh para guru, karakteristik peserta didik dapat dilihat dari perkembangan fisik, motorik, kognitif, emosi, sosial, dan religiusitasnya. (1) Perkembangan Fisik Anak Usia Sekolah Dasar: Masa usia SD merupakan periode pertumbuhan fisik yang lambat dan relatif seragam sampai kemudian mulai terjadi perubahan-perubahan pubertas, kira-kira dua tahun menjelang anak menjadi matang secara seksual. Oleh karena itu, masa ini sering disebut juga sebagai "periode tenang" sebelum pertumbuhan yang cepat menjelang masa remaja, meskipun merupakan masa tenang, tetapi hal ini tidak berarti bahwa pada masa ini tidak terjadi proses pertumbuhan fisik yang berarti. Pada masa ini peningkatan berat badan anak lebih banyak dari pada panjang badannya. Peningkatan berat badan anak selama masa ini terjadi terutama karena bertambahnya ukuran system rangka dan otot, serta ukuran beberapa organ tubuh. Pada saat yang sama kekuatan otot-otot secara berangsur-angsur bertambah dan gemuk bayi (baby fat) berkurang. Pertam bahan kekuatan otot ini adalah karena faktor keturunan dan latihan (olah raga). Karena faktor perbedaan jumlah sel-sel otot, maka pada umumnya untuk anak laki-laki Jebih kuat dari pada anak perempuan. 2) Perkembangan motorik. Dengan terus bertambahnya berat dan kekuatan badan, maka pada masa ini perkembangan motorik menjadi lebih halus dan lebih terkoordinasi dibandingkan dengan awal masa anak-anak. Anak-anak terlihat Jebih cepat dalam berlari dan makin pandai meloncat, anakjuga makin mampu menjaga keseimbangan badannya (Desmita 2006).

Untuk memperhalus keterampilan-keterampilan motoric, anak-anak terus melakukan berbagai aktifitas fisik yang terkadang bersifat informal dalam bentuk permainan. Disamping itu, anak-anakjuga melibatkan diri 
dalam aktivitas permainan olah raga yang bersifat formal, seperti senam, berenang, dan lain sebagainya. 3) Perkembangan kognitif. Seiring dengan masuknya anak ke Sekolah Dasar, kemampuan kognitifnya turut mengalami perkembangan yang pesat. Dengan masuk sekolah, berarti dunia dan minat anak bertambah luas. Dengan meluasnya minat maka bertambah pula pengertian tentang manusia dan objek-objek yang sebelumnya kurang berarti bagi anak (Sulistyowati, 2012).

Dalam keadaan normal, kemampuan berfikir anak usia Sekolah Dasar berkembang secara berangsur-angsur. Kalau pada masa sebelumnya daya fikir anak masih bersifat imaj inatif dan egosentris maka pada masa ini daya pikir anak · berkembang kearah berpikir kongkrit, rasional dan objektif. Daya ingatnya menjadi sangat kuat sehingga anak benar-benar berada dalam suatu stadium belajar. Menurut teori Piaget, pemikiran anak masa Sekolah Dasar disebut sebagai pemikiran operasional kongkrit (concrete operational thought), artinya aktivitas mental lebih bisa difokuskan pada objek-objek peristiwa nyata atau kongkrit. Dalam upaya memahami alam sekitarnya mereka tidak lagi terlalu mengandalkan informasi yang ber- sumber dari panca indera, karena anak mulai mempunyai kemampuan untuk membedakan apa yang tampak oleh mata dengan kenyataan sesung- guhnya (Sulistyowati, 2012)

Perkembangan emosi, sejak masuk Sekolah Dasar, keinginan anak untuk menjadi anggota kelompok dan dapat diterima oleh kelompok sebayanya semakin meningkat. Keterampilan sosial menjadi penting, terutama mengenali peran sosial seseorang. Anak memusatkan perhatian untuk dapat berhubungan dan berkomunikasi dengan ternan-ternan sebayanya. Anak belajar untuk memberi dan menerima diantara temantemannya dan berkeinginan untuk ikut berpartisipasi dalam kegiatankegiatan kelompok. Pada masa ini, pengertian anak tentang baik- buruk, tentang norma-norma aturan serta nilai-nilai yang berlaku di lingkungannya menjadi bertambah dan juga lebih fteksibel, tidak sekaku saat usia kanak-kanak awal. Mereka mulai memahami bahwa penilaian baik-buruk atau aturan-aturan dapat diubah tergantung dari keadaan atau situasi munculnya perilaku tersebut. Nuansa emosi mereka juga makin beragam (Zulkifli 2005).

\section{Tujuan Pendidikan Agama Islam di Sekolah Dasar}

Pendidikan agama Islam di sekolah bertujuan untuk menumbuhkan, mengembangkan dan meningkatkan keimanan melalui pemberian dan pemupukan pengetahuan, penghayatan, pengamalan peserta didik tentang ajaran agama Islam, sehingga menjadi manusia muslim yang terus berkembang dalam hal keimanan, ketakwaannya, berbangsa dan bernegara, serta untuk dapat melanjutkan pada jenjang pendidikan yang lebih tinggi. 
Oleh karena itu, berbicara pendidikan agama Islam, baik makna dan tujuannya haruslah mengacu pada penanaman nilai-nilai Islam dan tidak dibenarkan melupakan etika dan moralitas sosial. Penanaman nilai-nilai juga dalam rangka menuai keberhasilan hidup di dunia bagi peserta didik, yang kemudian akan mampu membuahkan kebaikan di akhirat kelak (Sulistyowati, 2012).

Pendidikan Agama Islam dimaksudkan untuk meningkatkan potensi spritual dan membentuk peserta didik agar menjadi manusia beriman dan bertakwa kepada Tuhan Yang Maha Esa dan berakhlak mulia (Rizal, 2014). Pendidikan Agama Islam diberikan dengan mengikuti tuntunan bahwa agama diajarkan kepada manusia dengan visi untuk mewujudkan manusia yang bertakwa kepada Allah SWT dan berakhlak mulia, serta bertujuan untuk menghasilkan manusia yang jujur, adil, berbudi pekerti, etis, saling menghargai, disiplin, harmonis dan produktif, baik personal maupun sosial. Tuntunan visi ini mendorong dikembangkannya standar kompetensi sesuai dengan jenjang persekolahan yang secara nasional ditandai dengan ciri-ciri: ( 1) Lebih menitik-beratkan pencapaian kompetensi secara utuh selain penguasaan materi; (2) Mengakomodasikan keragaman kebutuhan dan sumber daya pendidikan yang tersedia. (3) Memberikan kebebasan yang lebih luas kepada pendidik untuk mengembangkan strategi dan program pembelajaran sesuai dengan kebutuhan dan ketersediaan sumber daya pendidikan (Sulistyowati, 2012).

Melalui pendidikan agama Islam diharapkan menghasilkan manusia yang selalu berupaya menyempurnakan iman, takwa, dan akhlak, serta aktif membangun peradaban dan keharmonisan kehidupan, khususnya dalam memajukan peradaban bangsa yang bermartabat. Manusia seperti itu diharapkan tangguh dalam menghadapi tantangan, hambatan, dan perubahan yang muncul dalam pergaulan masyarakat baik dalam lingkup lokal, nasional, regional maupun global. Pendidik diharapkan dapat mengembangkan metode pembelajaran sesuai dengan Standar Kompetensi dan Kompetensi Dasar yang telah ditetapkan. Pencapaian seluruh Kompetensi Dasar perilaku terpuji dapat dilakukan secara tidak formal. Peran semua unsur sekolah, orang tua siswa, dan masyarakat sangat penting dalam mendukung keberhasilan pencapaian tujuan pendidikan agama Islam (Sulistyowati 2012). Dengan akhir pencapaian menjadi manusia yang sempurna di hadapan Allah.

\section{Materi Pendidikan Agama Islam di Sekolah Dasar}

Pendidikan Agama Islam di Sekolah Dasar memiliki kurikulum tersendiri, dalam pengembangan kurikulum ini menurut Rusman (2013, hlm. 4), ada 5 langkah yang harus dilakukan oleh seorang guru, yakni: (a) Perencanaan Proses Pembelajaran. (b) Prinsip-Prinsip Penyusunan 
Rencana (c) Pelaksanaan Pembelajaran. (d) Penilaian Pembelajaran. (e) Pengawasan pembelajaran (Suyadi, 2014). Dengan memperhatikan 5 langkah tersebut maka materi yang hendak disampaikan akan terorganisir dengan baik. Sesuai dengan kurikulum, maka kegiatan pembelajaran pendidikan agama Islam dapat dilaksanakan dengan baik. Segala sesuatu yang telah diprogramkan dalam kurikulum akan dilaksanakan dalam kegiatan pembelajaran. Artinya, kurikulum yang telah disusun dan direncanakan itu tidak terbatas pada sejumlah mata pelajaran, namun meliputi segala sesuatu yang dapat mempengaruhi perkembangan siswa baik pada saat masih menimba ilmu pengetahuan di sekolah yang bersangkutan atau sudah lulus dari sekolah (Suyadi 2014)

Mata pelajaran di SD diarahkan pada pendekatan tematik-integratif, kecuali beberapa mata pelajaran yang berdiri sendiri. Pendidikan agama, termasuk pendidikan agama Islam, adalah pelajaran yang berdiri sendiri, serupa dengan mata pelajaran pendidikan jasmani, olahraga dan kesehatan. Buku Pendidikan Agama Islam dan Budi Pekerti (PAI-BP) ditulis dengan pendekatan multidisipliner yang diberikan selama 35 menit kali 4 (empat) jam pertemuan perpekan. Buku siswa PAI-BP SD dicetak dengan gambargambar ilustrasi menarik. Sedangkan buku pendidik dicetak dengan penjelasan cukup sistematis dan memberikan arahan agar pendidik mampu mengembangkan pembelajaran. Pendidik ditempatkan pada posisi penting dalam pembelajaran menggunakan buku ini. Pendidik diharapkan untuk mampu meningkatkan dan menyesuaikan daya serap peserta didik dengan ketersediaan kegiatan yang ada pada buku ini. Pendidik diharapkan dapat memperkaya dengan kreasi dalam bentuk kegiatan- kegiatan lain yang bersumber dari lingkungan alam, sosial, dan budaya sekitar (Shunhaji, 2019).

Buku ini memuat lima kategori ruang lingkup kajian pendidikan agama Islam. Menurut Rianawati, ruang lingkup kajian pendidikan agama Islam yaitu Al-Qur'an, akidah, akhlak, fiqh/ibadah, dan sejarah kebudayaan Islam. Pembahasan tentang fiqh atau ibadah dapat dimasukkan pada ruang lingkup akhlak, yaitu akhlak kepada Allah SWT, akhlak terhadap diri sendiri, akhlak terhadap sesama, dan akhlak terhadap lingkungan. Dalam pembelajaran Al-Qur'an pendidik diminta untuk memberikan contoh bacaan yang benar, membimbing membaca dengan cara yang benar, menulis ulang, hingga menggali pesan ayat-ayat yang dipelajari. Adapun materi Al-Qur'an yang diajarkan adalah:

a) Kelas 1: QS. Al-Fâtihah/1: 1-7, Q.S Al-Ikhlâs/112: 1-4, huruf hijaiyah dan harakat.

b) Kelas 2: QS. An-Nâs/114: 1-6, QS. Al-'Ashr/103: 1-3, huruf sambung 
c) Kelas 3: QS. An-Nashr/110: 1-3, QS. Al-Kautsar/108: 1-3, QS. Ali'Imran/3: 159, QS. Al-Isra'/17: 26-27, QS. Al-Baqarah/2: 263, QS. AlQamar/54: 17, QS. Ar-Ra'd/13: 28, QS. Al-A'raf/7: 55, QS. AlMu'min/40: 60.

d) Kelas 4: QS. Al-Falaq/113: 1-5, QS. Al-Fîl/105: 1-5, QS. At-Taubah/9: 119, QS. Luqmân/31: 14, QS. Al-Hadid/57: 9, QS. Al-'Alaq/96: 1-5, QS. Al-Isra'/ 17: 27 dan 37,

e) Kelas 5: QS. At-Tîn/95: 1-8, QS. Al-Ma'ûn/107: 1-7, QS. AlFurqân/25: 67, QS. Al-Isra'/17: 27, QS. Luqman/31: 13, 17, 18

f) Kelas 6: QS. Al-Kafirûn/ 109: 1-6 (kelas 6), QS. Al-Qâri’ah/101: 1-11 (kelas 6), QS. Az-Zalzalah/99: 1-8 (kelas 6). QS. Al-Mâidah/5: 2-3 (kelas 6), QS. Al- Hujurât/49: 12-13 (kelas 6).

Dalam kontek mengajarkan Al-Qur'an yang demikian, pendidik hendaknya memiliki kompetensi yang sesuai. Namun, hingga saat ini belum ditemukan data yang jelas terkait dengan kompetensi guru PAI dalam mengajarkan Al-Qur'an. Terkait materi akidah, PAI-PB dalam buku ini mengajarkan pengetahuan tentang iman kepada Allah swt dengan sifat wujud, Maha Esa, Al-Malik, dua kalimat syahadat (kelas 1), Al-khaliq dan As-Salam (kelas 2), Maha Pemberi, Maha Mengetahui, Maha Mendengar (kelas 3), Al-Bashîr, Al-'Adl, Al-Adzîm (kelas 4), Al-Mumît, Al-hayyu, AlQayyûm, Al-Ahad (kelas 5), As-Shamad, Al-Muqtadir, Al- Muqaddim, AlBâqy (kelas 6). Selain pembelajaran beriman kepada Allah, buku ini juga mengajarkan beriman kepada Rasulullah, iman kepada malaikat (kelas 4) iman kepada kitab suci (kelas 5), iman kepada hari akhir serta iman kepada qadha dan qadar (kelas 6) (Shunhaji, 2019).

Terkait iman kepada rasulullah, buku ini memberikan cerita singkat para nabi dan rasul. Nama-nama nabi dan rasul yang dituangkan dalam buku ini adalah Nabi Adam AS, Nabi Idris AS, Nabi Nuh AS, Nabi Hud AS (kelas 1), Nabi Shaleh AS, Nabi Ya'qub AS, Nabi Ishaq AS (kelas 2), Nabi Yusuf AS, Nabi Syu'aib AS, Nabi Ibrahim AS, Nabi Ismail AS (kelas 3), Nabi Musa AS, Nabi Ayyub AS, Nabu Dzulkifli AS, Nabi Harun AS (kelas 4), Nabi Daud AS, Nabi Sulaiman AS, Nabi Ilyas AS, Nabi Ilyasa' AS (kelas 5), Nabi Yunus AS, Nabi Zakaria AS, Nabi Yahya AS, Nabi Isa AS (kelas 6). Kajian tentang riwayat dan keteladanan Nabi Muhammad SAW ada pada setiap jenjang kelas. Pengenalan nama-nama nabi dan rasul tampak kurang mendalam. Nabi dan rasul dikenalkan melalui sikap yang berhubungan dengan tema subbab pembahasan, misalnya nabi Daud dikenalkan sebagai sosok pemberani, nabi Yunus dikenalkan sebagai sosok yang bertanggungjawab, dan sebagainya. Pembelajaran keimanan dengan cara mengenalkan Allah SWT, malaikat, rusul, kitab, hari akhir, dan qadla qadar secara sekilas seperti yang dipaparkan dalam buku guru maupun 
buku siswa, mengembangkan aspek kognitif pada tahap sensor motor (Shunhaji, 2019).

Dalam pandangan Piaget, pengembangan kognitif tahap ini masih pada level awal. Sandra Johnson menyebutkan pendapat Piaget terkait perkembangan kognisi anak. Johnson menuliskan bahwa; His theory described four stages of development: the sensorimotor stage from birth to 2 years (exploration and learning through senses and movement), pre-operational stage, 27 years (magical thinking, acquisition of motor skills and egocentricity), concrete operational stage 7-11 years (logical thinking begins but concrete, less egocentric), and formal operational stage, 11-16 yers and beyond (abstract reasoning and logical thinking (Shunhaji, 2019).

Selain pembelajaran di atas, pendidikan akhlak cukup banyak diajarkan oleh PAI-PB melalui buku-buku ini. Di kelas satu, peserta didik diajarkan kasih sayang melalui cerita kasih sayang Allah SWT dan Nabi Muhammad SAW. Mereka juga diajarkan tentang rajin belajar, berkata baik, hormat dan patuh, mensyukuri karunia pemberian, pemaaf, jujur, percaya diri. Dalam hal ibadah, peserta didik kelas satu diajarkan tata cara bersuci, shalat wajib, dan mengaji di lingkungan sekitar. Pendidikan akhlak terhadap sesama menjadi penekanan yang sangat mendasar dan mengambil porsi besar dalam PAI-BP ini. Sikap-sikap sosial seperti peduli lingkungan, kerjasama, tolong menolong, kasih sayang sesama (kelas 2), tanggungjawab, tawaddu', peduli sesama, bersyukur (kelas 3), rendah hati, hemat, gemar membaca, pantang menyerah, hormat dan patuh, menghargai teman, santun (kelas 4), hidup sederhana, ikhlas, saling menghargai, hormat dan patuh orang tua dan guru, hidup sederhana dan ikhlas (kelas 5), tanggungjawab, kasih sayang, patuh, taat, peduli, serta teguh pendirian (kelas 6). Sikap sosial di atas digambarkan melalui ceritacerita rusul, orang shalih, dan walisongo. Pembelajaran PAI-PB ini memenuhi standar pembelajaran yang tersistematis (Shunhaji, 2019).

Menurut Oemar Hamalik, standar pembelajaran tersistematis memuat rencana, saling ketergantungan (interdependence) dengan tujuan (Hamalik 2017). Upaya melalukan pembelajaran dengan sistematika terstruktur demikian hendaknya diimbangi dengan kompetensi pendidik PAI-PB sesuai standar. Kemampuan pendidik bukan sekedar kemampuan menyampaikan materi pelajaran. Keberhasilan pendidikan di kelas membutuhkan suasana yang mendukung. Oleh karena itu, pembelajaran dengan cara damai (penetration pacifique) sangat menunjang keberhasilannya. PAI-PB saat ini memberikan porsi lebih banyak pada pendidik. Pendidik terlibat dalam merencanakan, melaksanakan, dan melakukan penilaian terhadap proses pembelajaran PAI-BP. Pendidik diharuskan mampu memahami setiap bab yang berisi kompetensi inti, kompetensi dasar, tujuan pembelajaran, prosespembelajaran, penilaian, 
pengayaan, remedial, dan interaksi antara pendidik dan orang tua. Pendidik juga harus mampu memahami karakteristik peserta didik untuk dapat melakukan proses pembelajaran, penilaian, pengayaan, dan remedial yang tepat (Shunhaji, 2019).

\section{Metode Pendidikan Agama Islam di Sekolah Dasar}

Secara harfiah, metodologi dapat diartikan dengan sekumpulan metode atau cara untuk melakukan sesuatu atau dengan kata lain dalam kontek ini adalah sekumpulan metode atau cara untuk melakukan kegiatan pendidikan. Dalam bahasa Arab kata metode diungkapkan dalam berbagai kata seperti kata al-thariqah, al-manhaj. Al-thariqah berarti jalan, al-manhaj berarti sistem. Dengan demikian, kata Arab yang paling dekat dengan arti metode adalah al- thariqah (Ismail 2009). Metodologi pendidikan agama Islam bisa difahami sebagai pengetahuan tentang berbagai upaya yang terencana dan sistematis dalam pelaksanaan kegiatan pendidikan agama Islam dalam rangka pencapaian tujuan pendidikan nasional. Zuhairini dkk mengatakan metodologi pendidikan agama dengan segala usaha sistematis dan pragmatis untuk mencapai tujuan pendidikan agama dengan melalui aktifitas baik di dalam maupun di luar kelas dalam lingkungan sekolah (Zuhairini 1983). Adapun metode pengajaran agama Islam adalah cara yang paling tepat dan cepat dalam mengajarkan agama Islam (Tafsir 2007).

Peranan metode dalam pendidikan berasal dari kenyataan bahwa materi pendidikan tidak akan dapat dikuasai kecuali dengan menggunakan metode yang tepat. Ketidak tepatan dalam penerapan metode akan menghambat proses belajar-mengajar yang berakibat pada gagalnya mencapai tujuan yang ditetapkan. Ada pula batasan yang lebih luas, tidak terbatas pada cara atau jalan yang ditempuh. Metode pendidikan dapat diartikan sebagai segala kegiatan yang dilakukan oleh pendidik dalam proses pendidikan sehingga memungkinkan peserta didik mencapai suatu tujuan (Al-Syaibany 1979).

Dari pengertian di atas dapat difahami bahwa metode pendidikan adalahcara yang ditempuh atau jalan yang dilalui oleh pendidik untuk mencapai tujuan pendidikan. Metode pendidikan terkait erat dengan tujuan pendidikan, pendidik, peserta didik, maupun nilai dan norma yang mendasari pendidikan itu. Adapun beberapa metode pendidikan Islam yang perlu diterapkan di sekolah, beberapa di antaranya adalah sebagai berikut:

a) Metode Ams்àl: Secara lughawi amíāl adalah membuat pemisalan, perumpamaan dan bandingan (Syahidin, 2009, hlm. 79). Sedangkan

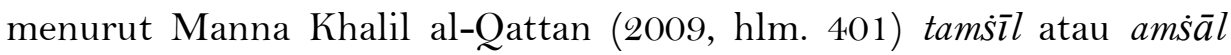
merupakan kerangka yang dapat menampilkan makna-makna dalam bentuk yang hidup dan mantap didalam pikiran, dengan cara menyerupakan sesuatu yang gaib dengan yang hadir, yang abstrak 
dengan yang konkrit, dan dengan menganalogikan sesuatu dengan yang serupa. Tamsīl lebih dapat mendorong jiwa untuk menerima makna yang dimaksudkan dan membuat akal merasa puas dengannya.

b) Metode kisah Qurāni: Kisah berasal dari bahasa Arab, yakni dari kata

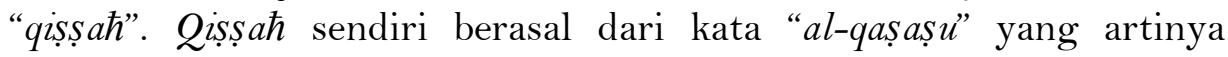
mencari jejak. Secara terminologis, kata "qișșa Alquran" mengandung dua makna yaitu, pertama: "al-qașaș fi Alquran" yang artinya pemberitaan Alquran tentang hal ikhwal umat terdahulu, baik informasi tentang keNabian maupun tentang peristiwa-peristiwa yang terjadi pada umat terdahulu. Kedua, "qașaș Alquran" yang artinya karakteristik kisah-kisah dalam Alquran. Pengertian yang kedua inilah yang dimaksud kisah sebagai metode pendidikan (Syahidin, 2009, hlm. 94).


suatu upaya untuk mengambil pelajaran dari pengalaman-pengalaman orang lain atau dari peristiwa-peristiwa yang terjadi di masa lampau melalui suatu proses berpikir secara mendalam, sehingga menimbulkan kesadaran pada diri seseorang (Syahidin, 2009, hlm. 110). Adapun maw'izaћ didefinisikan oleh Abdurrahman An-Nahlawi (dalam Syahidin, 2009, hlm. 110) sebagai sesuatu yang dapat mengingatkan seseorang akan apa yang dapat melembutkan kalbunya yang berupa pahala atau siksa sehingga menimbulkan pula kesadaran dalam diri, atau bisa saja berbentuk sebagai nasehat dengan cara menyentuh kalbu.

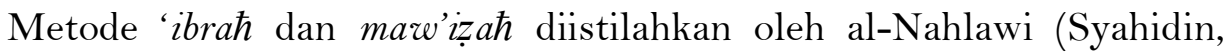
2009, hlm. 117) sebagai pendekatan pendidikan keimanan dalam Alquran atau disebut sebagai metode Qurāniyyah yang memiliki berbagai keistimewaan karena ada keselarasan dengan fitrah manusia sebagai pendidik dan terdidik.

d) Targib- Tarhib: Targib adalah strategi atau cara untuk meyakinkan seseorang terhadap kebenaran Allah melalui janji-Nya yang disertai dengan bujukan dan rayuan untuk melakukan amal shaleh. Sedangkan tarhib adalah strategi untuk meyakinkan seseorang terhadap kebenaran Allah melalui ancaman dengan siksaan sebagai akibat melakukan perbuatan yang dilarang oleh Allah (Syahidin, 2009, hlm. 125).

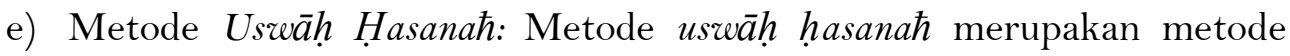
yang digunakan dengan cara memberikan contoh teladan yang baik, yang tidak hanya memberi didalam kelas, tetapi juga dalam haliah sehari-hari (Mujib \& Mudzakkir, 2008, hlm. 197). Metode uswāh hasanah ini, menurut Syahidin (2009, hlm. 150) adalah sebuah metode yang dianggap paling besar pengaruhnya terhadap keberhasilan proses 
belajar mengajar, dengan memeberikan contoh yang baik kepada para peserta didik, baik dalam ucapan maupun perbuatan.

f) Metode Hiwār Qurāni: Hiwār Qurāni dapat diartikan sebagai dialog, yakni suatu percakapan atau pembicaraan silih berganiti antara dua pihak atau lebih yang dilakukan melalui tanya jawab, didalamnya terdapat kesatuan topik pembicaraan dan tujuan yang hendak dicapai dalam pembicaraan itu, dialog-dialog tersebut terdapat dalam Alquran dan al-Sunnah (Syahidin, 2009, hlm. 163).

Berbagai metode yang telah dipaparkan di atas, merupakan sebuah metode yang tepat untuk diterapkan dalam dunia pendidikan, karena AlQuran menjadi sumber yang utama. Dengan penerapan metode yang sesuai, informasi ilmu yang diberikan oleh pendidik kepada peserta didik dapat terserap lebih cepat, sehingga metode yang digunakan dapat menjadi faktor penunjang keberhasilan tujuan pendidikan (Darmiah, 2019).

\section{Evaluasi Pendidikan Agama Islam di Sekolah Dasar}

Evaluasi menurut pendidikan Islam ialah cara atau upaya penilaian tingkah laku peserta didik berdasarkan perhitungan yang bersifat menyeluruh, meliputi aspek-aspek psikologis dan spiritual, karena pendidikan Islam tidak hanya melahirkan manusia didik yang berilmu saja atau bersikap religius saja namun juga manusia didik yang memiliki keduanya yakni manusia didik yang berilmu serta bersikap religius, beramal baik dan berbakti kepada tuhan serta masyarakat (Nata, 2003). Dengan demikian evaluasi yang diterapkan pendidikan Islam bukan hanya sekedar menilai suatu aktivitas secara spontan dan insedental, melainkan merupakan kegiatan untuk menilai sesuatu dengan terencana, sistematik, berdasarkan tujuan yang jelas dan komprehensif mencakup keseluruhan aspek yang ada dalam siswa baik secara psikologis, religius maupun segi keilmuan (Suharna, 2016).

Pengukuran memiliki arti yang berkaitan dengan evaluasi. Namun pengukuran berkaitan dengan data yang bersifat angka atau kuantitatif dalam mengumpulkan informasi akan sesuatu yang akan diukur, dan di dalam pengukuran diperlukan data kuantitatif lain untuk pembanding dari data kuantitatif yang akan diukur (Ramayulis, 2008), karena pengukuran berkaitan dengan angka-angka maka pengukuran memerlukan alat ukur tertentu untuk dapat memperoleh hasil dari data kuantitatif. Pengukuran pun sangat di perlukan dalam dunia pendidikan, karena pengukuran dalam dunia pendidikan dapat digunakan untuk menilai kondisi yang bersifat objektif dalam diri siswa maupun stakeholder sekolah. Demikian pula dalam melaksanakan evaluasi pendidikan Islam pengukuran sangat diperlukan untuk dapat menilai berbagai keadaan yang bersifat obyektif, walaupun 
pengukuran memiliki istilah yang sama dengan evaluasi namun pengukuran tidak berarti sama dengan evaluasi (Sari, 2019).

Mengenai evaluasi pendidikan agama Islam ini terkadang terjadi hal-hal yang di luar dugaan. Misalnya ada peserta didik yang jarang sekolah, malas dan merasa terpaksa mengikuti pelajaran agama, tetapi ketika dievaluasi dia mendapatkan nilai yang lebih tinggi dibandingkan dengan peserta didik yang rajin belajar agama. Artinya yang salah itu adalah evaluasinya karena yang dilakukan hanyalah mengukur unsur kognitifnya saja. Oleh karena itu evaluasi pendidikan agama Islam jangan hanya mengandalkan evaluasi kemampuan kognitif saja, tetapi harus dievaluasi juga sikap (afektif), dan prakteknya atau keterampilan (psikomotor). Guru melakukan pengamatan terhadap perilaku sehari-hari peserta didik tersebut apakah peserta didik itu shalat? Kalau dilaksanakan apakah shalatnya benar sesuai tata caranya? Evaluasi ini sebetulnya menentukan status peserta didik tentang hasil belajarnya itu apakah sudah mencapai tujuan yang ingin dicapai atau tidakKalau tujuan agama itu adalah supaya peserta didik bisa menjalankan agama Islam dengan baik maka evaluasinya harus sesuai, dan evaluasinya itu bukan hanya hafal tentang kaidah- kaidah tentang kemampuan kognitif saja tetapi juga yang bersifat praktikal.

Berkaitan dengan evaluasi pendidikan agama Islam, ada usulan yang kuat dari berbagai kalangan agar pendidikan agama Islam sebaiknya masuk pada ujian nasional, sehingga menjadi bahan untuk dipertimbangkan peserta didik lulus atau tidak lulus di suatu lembaga pendidikan (Sholihah and Machali, 2017). Ujiannya jangan sekedar mengukur kemampuan kognitif melainkan juga kemampuan yang bersifat psikomotor, praktek dan perilaku, serta sikap peserta didik sebagai orang yang menganut ajaran agama Islam (Kosim, 2015). Dengan demikian evaluasi dalam pembelajaran pendidikan Agama Islam bisa secara verbal ataupun non verbal, tulis maupun non tulis yang ditujukan untuk mengukur komptensi intelektual, kompetensi sosial, kompetensi sosial dan kompetensi spiritual.

\section{Kesimpulan}

Pendidikan Agama Islam (PAI) sebagai salah satu mata pelajaran yang diajarkan di sekolah memiliki peranan yang sangat strategis untuk membentuk kepribadian peserta didik yang tangguh; baik dari segi moralitas maupun dari aspek sains dan teknologi. Pendidikan Islam sebagai subsistem pendidikan nasional yang sesuai dengan UU No. 2, tahun 1989, dalam pelaksanaan pendidikan agama Islam di pendidikan formal atau sekolah mempunyai dasar-dasar yang sangat kuat, yakni dasar yuridis, 
dasar riligiuos, dan dasar psikologis. Dalam perkembangannya anak usia Sekolah Dasar memiliki ciri khasnya tersendiri, kemampuan berfikir anak usia Sekolah Dasar berkembang secara berangsur-angsur. Jika pada masa sebelumnya daya fikir anak masih bersifat imajinatif dan egosentris maka pada masa ini daya pikir anak berkembang kearah berpikir kongkrit, rasional dan objektif. Adapun ruang lingkup kajian pendidikan agama Islam yaitu Al-Qur'an, akidah, akhlak, fiqh/ibadah, dan sejarah kebudayaan Islam. Metode pendidikan yang bisa diterapkan mengacu kepada metode Qurani yakni metode amstal, metode qishah, metode ibrah mauidzah, metode hiwar jadali, metode uswah hasanah, dan metode targhib tarhib. Sementara itu, evaluasi yang diterapkan pendidikan Islam bukan hanya sekedar menilai suatu aktivitas secara spontan dan insedental, melainkan merupakan kegiatan untuk menilai sesuatu dengan terencana, sistematik, berdasarkan tujuan yang jelas dan komprehensif mencakup keseluruhan aspek, baik dari segi kognitif, afektif dan psikomotorik, dan evaluasi pembelajaran pendidikan Agama Islam bisa dilaksanakan secara secara verbal ataupun non verbal, tulis maupun non tulis yang ditujukan untuk mengukur komptensi intelektual, kompetensi sosial, kompetensi sosial dan kompetensi spiritual. Dengan demikian, pendidikan agama Islam di sekolah dasar bertujuan untuk menumbuhkan, mengembangkan dan meningkatkan keimanan melalui pemberian dan pemupukan pengetahuan, penghayatan, pengamalan peserta didik tentang ajaran agama Islam, sehingga menjadi manusia muslim yang terus berkembang dalam hal keimanan, ketakwaannya, berbangsa dan bernegara, serta untuk dapat melanjutkan pada jenjang pendidikan yang lebih tinggi. Melalui pendidikan agama Islam diharapkan menghasilkan manusia yang selalu berupaya menyempurnakan iman, takwa, dan akhlak, serta aktif membangun peradaban Islam.

\section{DAFTAR PUSTAKA}

Al-Syaibany, Omar Muhamad Al-Taomi. 1979. Falsafah Pendidikan Islam. Jakarta: Bulan Bintang.

Budiyanti, Nurti, Ahmad Syamsu Rizal, and Elan Sumarna. 2016. "Implikasi Konsep Ūlūl 'Ilmi dalam Al-Qur`Ān Terhadap Teori Pendidikan Islam (Studi Analisis Terhadap Sepuluh Tafsīr Mu'Tabarah)." TARBAWY: Indonesian Journal of Islamic Education.

Darmiah, Darmiah. 2019. "Strategi Pembelajaran Pendidikan Agama Islam Di Sekolah Lanjutan Menengah Atas Dan Pengaruhnya Terhadap 
Pembangunan Karakter.” PIONIR: Jurnal Pendidikan 53(9): 168999.

Desmita. 2006. Psikologi Perkembangan. Bandung, Rosdakarya.

Efendi, Saprin, Saiful Akhyar Lubis, and Wahyuddin Nur Nasution. 2018.

"Problematika Pembelajaran Pendidikan Agama Islam Di Sd

Negeri 064025 Kecamatan Medan Tuntungan.” EDU RILIGIA Journal Vol 2(No 2): 265-75.

Fakhruddin, Agus. 2014. "Urgensi Pendidikan Nilai Untuk Memecahkan Problematika Nilai Dalam Konteks Pendidikan Persekolahan."

Jurnal Pendidikan Agama Islam-Ta'lim 12(1): 79-96. http://jurnal.upi.edu/file/07_-_Urgensi_Pendidikan_Nilai__Agus_F.pdf.

Hartati, Afiatun Sri. 2015. "Dinamika Pembelajaran Pendidikan Agama Islam (Pai) Di Sekolah Dasar." Cendekia: Jurnal Kependidikan dan Kemasyarakatan 13(1): 87.

Hartati, Sri. 2017. "Konsep Spiritual Parenting Dengan Pendekatan Konseling Behavioristik Dalam Membentuk Moral Anak Usia Sekolah Dasar." Http://Ejournal.Stkipbbm.Ac.Id/4(1): 40-52. http://ejournal.stkipbbm.ac.id/index.php/pgsd/article/viewFile/ 102/99.

Hamalik, Omar. 2017. Kurikulum dan Pembelajaran. Jakarta: Bumi Aksara.

Ismail. 2009. Stratgei Pembelajaran Agama Islam berbasis PAIKEM. Semarang: RASAIL.

Kosim, Nandang. 2015. "Pengembangan Dan Aplikasi Pembelajaran Pai Di Sd." Qathrunâ 2(2): 121-42.

Majid, Abdul. 2004. Pendidikan Agama Islam Berbasis Kompetensi: Konsep dan Implementasi Kurikulum 2004. Bandung: Remaja Rosdakarya.

Nata, Abuddin. 2003. "Manajemen Pendidikan Mengatasi Pendidikan Islam Di Indonesia." Ilmu Pendidikan.

Rizal, Ahmad Syamsu, and Abstrak. 2014. "Perumusan Tujuan Sebagai Basis Pengembangan Kurikulum Pendidikan Islam.” Jurnal Pendidikan Agama Islam -Ta'lim.

Sari, Lia Mega. 2019. "Evaluasi Dalam Pendidikan Islam.” Al-Tadzkiyyah: Jurnal Pendidikan Islam 9(2): 211.

Sholihah, Zumrotus, and Imam Machali. 2017. "Pendidikan Agama Islam Di Sekolah Alternatif Sd Sanggar Anak Alam ( Salam )." Cendekia 15(2): 226-40. 
Shunhaji, Akhmad. 2019. "Agama Dalam Pendidikan Agama Islam Di Sekolah Dasar.” Andragogi: Jurnal Pendidikan Islam dan Manajemen Pendidikan Islam 1(1): 1-22.

Sofwan Nugraha, M, and Udin Supriadi dan Saepul Anwar. 2014. "Pembelajran Pai Berbasis Media Digital (Studi Deskriptip Terhadap Pembelajaran PAI Di SMA Alfa Centauri Bandung)." Jurnal Pendidikan Agama Islam -Ta'lim 12(1): 55-67.

Sulistyowati, Endang. 2012. "Pembelajaran PAI di Sekolah Dasar.” Jurnal Al-Bidayah 4(1): 63-76.

Suyadi, S. 2014. "Pelaksanaan Pembelajaran Pendidikan Agama Islam (Pai) Di Smk Negeri 1 Lais Kecamatan Lais Kabupaten Musi Banyuasin." Conciencia 14(1): 25-47.

Tafsir, Ahmad. 2007. Metodologi Pengajaran Agama Islam. Bandung: PT remaja Rosdakarya.

Tang, Muhammad. 2018. "Pengembangan Strategi Pembelajaran Pendidikan Agama Islam (PAI) Dalam Merespon Era Digital." Fikrotuna 7(1): 717-40.

Utomo, Khoirul Budi. 2018. "Strategi Dan Metode Pembelajaran Pendidikan Agama Islam MI.” MODELING:Jurnal Program Studi PGMI 5(2): 145-56.

Zuhairini. 1983. Metodik Khusus Pendidikan Agama. Surabaya: Usahan Nasional.

Zulkifli. 2005. Psikologi Perkembangan. Bandung: Rosdakarya. 